\title{
A crise da Unasul pelas agências internacionais de notícias: a veiculação do colapso da integração regional Sul-americana pela mídia
}

\section{Unasur's crisis by international news agencies: the reporting of the collapse of the South American regional integration by the media}

\author{
Beatriz Soares Bidarra \\ Jéssica Maria Grassi \\ Lucas Kerr Oliveira
}

\section{Resumo}

$\mathrm{O}$ artigo investiga o discurso perpetrado pela grande mídia no que se refere à crise interna pela qual a União das Naçôes Sul-Americanas (Unasul) enfrenta desde 2017. Para essa análise foram selecionadas e analisadas todas as notícias publicadas sobre o assunto nos sites de duas grandes agências de notícias internacionais, a Reuters e a EFE, no período de abril a agosto de 2018 - da suspensão das atividades de seis membros do bloco à notificação por parte da Colômbia de retirar-se do bloco. Parte-se da hipótese que a maneira como a mídia - representada neste estudo pelas agências de notícias selecionadas - ressignifica os acontecimentos, por meio do conteúdo midiático veiculado, pode reforçar discurso contrário à integraçáo sul-americana. Observa-se que os desafios da integração na América do Sul săo complexos, indo desde as assimetrias e a situação política e econômica dos países do bloco até o enfrentamento do discurso propagado pela grande mídia.

\section{Palavras-chave}

Integração Regional; América do Sul; Unasul; Mídia; Geopolítica de Comunicaçóes.

\begin{abstract}
This article investigates the discourse reported by the mainstream media regarding the internal crisis that the Union of South American Nations (Unasur) has faced since 2017. This research selected and analyzed all the news published on the websites of two major international news agencies, Reuters and EFE, from April to August 2018- from the suspension of the activities of six members of the bloc to the notification of Colombia's withdrawal from the block. Considering as a hypothesis that the way in which the media represented in this study by the selected news agencies - reframe events through the media content can reinforce discourse against South American integration. The challenges of South America integration are complex, running through the asymmetries and the political and economic situation of the bloc's countries, and also facing the discourse disseminated by the mainstream media.
\end{abstract}

\section{Keywords}

Regional Integration; South America; Unasur; Media; Geopolitics of Communications. 


\section{Introdução ${ }^{1}$}

A ligação entre as áreas das Relações Internacionais e da Comunicação é inegável. Contudo, ainda é incipiente o montante de pesquisa científica que interliga essas áreas do conhecimento. Nesse âmbito, algumas preocupações são comuns, como o acesso e controle da informação, dado que a última é utilizada como ferramenta para conquista e manutenção de poder. Por vezes, o que se percebe é a concretização das relações de poder mais diversas e complexas, mascaradas na prática jornalística, que, por sua vez, tende a ser pautada pela objetividade e neutralidade como critérios da prática profissional.

A partir disso, compreendendo que as relações de poder se estabelecem em vários âmbitos sociais e que os meios de comunicação são usualmente captados para a construção do discurso de interesse dos Estados, das elites políticas e empresariais, a presente pesquisa propóe a análise do discurso construído pela grande mídia acerca da integração sul-americana, mais especificamente analisando a crise enfrentada pela União das Naçóes Sul-Americanas (Unasul) em 2018 - e que precedeu ao seu quase completo desmanche. Nessa perspectiva, parte-se da hipótese de que a maneira como a mídia ressignifica os acontecimentos, por meio do conteúdo midiático veiculado, pode reforçar discurso contrário à integração sul-americana.

Assim, foram selecionadas as notícias relacionadas à referida crise vivida pela Unasul e à suspensão da participação de seis países-membros - Argentina, Colômbia, Chile, Brasil, Paraguai e Peru -, enfatizando, assim, o período entre a suspensão das atividades desses membros (abril de 2018) e a notificação por parte da Colômbia de retirar-se do bloco (agosto de 2018), primeiro país a fazer esse anúncio. Foram selecionadas duas importantes agências internacionais de notícias para fazer essa análise. A Reuters foi escolhida por ser a primeira e mais famosa agência de notícias do mundo e a EFE por ser a quarta agência internacional mais importante e a primeira em língua espanhola.

No que diz respeito à seleção das notícias, importa esclarecer que se pesquisou a palavra-chave "Unasul" nos sites das duas agências e foram selecionadas todas as notícias que se encontravam abertamente disponíveis, que efetivamente se relacionavam ao tema escolhido (a suspensão da participação de seis países-membros e a saída da Colômbia do bloco) e que foram divulgadas no período demarcado para o estudo.

\footnotetext{
${ }^{1}$ Os resultados parciais desta pesquisa foram apresentados no VI Encuentro de Estudios Sociales desde América Latina y Caribe.
} 
Quantitativamente, o estudo observa a frequência de alguns termos, partindo do conceito de "agendamento" (agenda-setting), que diz respeito ao que a mídia pauta ou coloca na agenda pública a respeito do assunto; e qualitativamente, a pesquisa observa o enquadramento dado às fontes, temas e à linguagem usada pelas notícias.

Portanto, o olhar que recai sobre as notícias se guia por meio da análise de agendamento midiático e enquadramento, observando o tratamento das reportagens a partir de categorias de análise do conteúdo. Para a pesquisa, que se iniciou em 2018, alguns pontos foram identificados de maneira preliminar e verificados para checar sua predominância nas notícias analisadas, dentre eles: visóes como ameaça, falta de consenso entre os países-membros, estagnação ou paralisia das iniciativas integracionistas e incapacidade dos países de se articularem para políticas de integração regional. Importa observar que a ausência de aparição e cobertura da Unasul nos veículos de comunicação também é fator importante, uma vez que a invisibilização desses temas nos meios de comunicação também é forma de silenciar o processo integracionista.

Este estudo também faz uma revisão bibliográfica discutindo questões históricas, teóricas e conceituais do tema proposto. Assim, observa-se uma pesquisa quantitativa e qualitativa, com um método de abordagem hipotético-dedutivo, que perpassa a análise de um caso específico - crise da Unasul - para compreender o discurso da grande mídia internacional acerca do processo integracionista sulamericano.

Para alcançar o objetivo proposto, o artigo se divide em três seções. Primeiramente, serão abordados conceitos e abrangência de agência de notícias, bem como influência histórica dos meios de comunicação em processos decisórios, especialmente em decorrência dos oligopólios de mídia estrangeira na América Latina. Em um segundo momento, serão explorados, de modo geral, o contexto da criação da Unasul, os desdobramentos e os desafios enfrentados desde entáo, na busca por compreender a crise desencadeada. Por fim, o estudo verificará de que forma a mídia coloca o tema na agenda pública, examinando as notícias veiculadas pelas duas agências internacionais de notícias elegidas para este estudo. 


\section{Difusão das agências de notícias: do direito à informação à autonomia comunicacional}

Os meios de comunicação possuem relevante papel de difusão, acesso, controle e pluralização da informação na sociedade. Por meio da ressignificação dos fatos em notícias é que se percebe e mensura a opinião pública. Nesse contexto, no cenário internacional, as agências internacionais de notícias possuem papel de destaque, uma vez que trabalham com a difusão da informação para outros veículos de comunicação de massa, em escala regional e, em grande parte, internacional.

Retomando um pouco a trajetória das agências, importa ressaltar que grande parte das agências de notícias surgem entre 1940 e 1980, contexto histórico que perpassa o período de Guerra Fria e é anterior às tecnologias de informação e à digitalização do jornalismo (GONÇALVES, 2010; AGUIAR, 2016). Embora algumas agências, como a Reuters, sejam anteriores a isso, a maioria das agências surge em um período de montagem de sistemas nacionais e internacionais de comunicação. E, nesse contexto, optou-se por privilegiar a criação de agências e não de meios tradicionais, como rádio e televisão, porque o custo operacional de agências de notícias é mais baixo e ao mesmo tempo permite uma difusão de informação em larga escala.

Ocorre que, desde seu surgimento, as agências de notícias caracterizavam-se como meios multiplicadores de conteúdo informativo jornalístico para outros meios de comunicação, construídas na lógica de mercado de venda de notícias rápidas e concisas para jornais, sites, rádio e qualquer outro meio de comunicação que adquirisse o conteúdo.

Como relata Aguiar (2016), as agências são disseminadoras de conteúdo externo e interno. Ademais, o autor aponta o fluxo de informação por meio de agências de notícias como importante elemento nas relações de poder.

Dentro das teorias da modernização, a corrente do difusionismo, a mesma de Schramm, defendia claramente que o processo de desenvolvimento seria difundido do centro do capital para a periferia, exigindo nesta a importação não apenas de infraestrutura, mas também de superestrutura: valores, ideologias, relaçóes de produção e de poder. (AGUIAR, 2016, p. 41).

De acordo com Gonçalves (2010, p. 426), as agências ainda atuam como eficiente setor de circulação na escala industrial de produção de notícias, uma vez que 
conseguem fornecer informação de forma rápida e simultânea. E, da mesma maneira que alimentam os conglomerados midiáticos, também são alimentadas por eles.

Conforme já exposto, este artigo discute e trabalha a análise midiática para duas agências internacionais: Reuters e EFE. Reuters e EFE estão entre as dez maiores agências de notícias do mundo, considerando o número alto de clientes e a presença em mais de 100 países. O histórico das agências remonta um cenário ligado ao interesse dos Estados. A Reuters, por exemplo, garantiu seu monopólio de infraestrutura de comunicação por meio de acordos com a Coroa Britânica (GONÇALVES, 2010).

A respeito do modelo em que elas se enquadram, Aguiar (2010, p. 24) explica,

[...] agências privadas (Reuters, UPI) têm interesses comerciais imediatos e, portanto, devem prestar serviços que se adequem producentemente ao "negócio" dos seus clientes, por sua vez sustentados por publicidade (de anunciantes privados ou estatais), na conhecida estrutura da mídia hegemônica; agências estatais (AFP, EFE, Tanjug) servem diretamente ao Estado e, particularmente, ao governo da vez, predominantemente ou em lugar do interesse público; agências "cooperativadas" (AP, ANSA) atendem às demandas dos assinantes que são seus próprios acionistas, reproduzindo de forma ainda mais direta o primeiro modelo, e perpetuando diretrizes e prioridades editoriais, além de evitar iniciativas (jornalísticas ou empresariais) consideradas "ousadas" ou "arriscadas" demais.

A Reuters é uma das mais antigas agências mundiais, remontando ao século XIX. Ela foi fundada em 1851 por um antigo funcionário da Agência Havas (atual France Press), com o objetivo de concorrer mundialmente com a agência francesa (REUTERS, 2020). Quase na mesma época, havia surgido outra agência de notícias importante no cenário internacional. Em 1845, vários jornais de Nova Iorque se juntaram e formaram a Associated Press, embora ela tenha sido registrada somente em 1892. Já na América do Sul, mais especificamente no Brasil, e no contexto midiático que tinha a figura de Assis Chateaubriand, ele próprio fundou a Meridional Press, em 1931. E, mais tarde, surgiu a Agência Estado e a Agência Brasil (GONÇALVES, 2010).

Conforme informaçôes do site da própria agência, a EFE, por sua vez, foi fundada oficialmente em 1939. Em 1966 começou o serviço de divulgação de 
notícias da agência para a América Latina e em 2001 houve o lançamento em português, voltado para o Brasil. Dessa forma, o veículo espanhol também ampliou sua presença tanto na América Latina como mundialmente (EFE, 2020).

O surgimento das agências de notícias em todo o mundo está muito relacionado à expansão do capitalismo, maximização dos lucros e a crescente busca por informação, fosse ela local, regional ou mundial. Tudo isso foi também propiciado pelo avanço tecnológico ao longo desses períodos mencionados. Tal contexto fez com que esse modelo de difusão em massa da informação se reproduzisse. As agências passaram, entáo, a serem vistas como setor estratégico para construção de espaço simbólico, embora primeiramente elas tenham surgido para fazer circular informaçóes sobre o mercado financeiro, como foi o caso da Havas. Outro fator importante a se considerar é que a aproximação das agências com os Estados sempre garantiu a elas alguns benefícios. A Reuters, por exemplo, em acordo com a Coroa Britânica, teria garantido para si o monopólio de cabos submarinos (GONÇALVES, 2010).

Importa ressaltar que alguns países emergentes, como China, Rússia e Índia, têm suas próprias agências voltadas para os interesses nacionais desenvolvimentistas e para a difusão desses interesses para a população de seus países, assim como para todo o mundo. $\mathrm{O}$ Brasil, entretanto, não conseguiu formar uma agência formada totalmente com capital público, com participação total da sociedade em suas produçôes e com essa potência de inserção de notícias nas esferas globais, como a Reuters consegue fazer.

Esse contexto é, de certa forma, permissivo ao abrir o mercado interno comunicacional ao capital estrangeiro. A falta de infraestrutura comunicacional também reflete no cenário de desenvolvimento tardio na área. Conforme destaca Gonçalves (2010), no Brasil, as agências de notícias internacionais começaram a ter mais presença no país a partir do final do século XIX, com a expansão dos cabos de telégrafo.

Em relação à presença das agências de notícias nos países dos BRICS, o caso brasileiro pode ser considerado, de certa forma, sui generis. A Rússia possui grandes conglomerados estatais ou semiestatais de mídia e notícias, sendo a principal agência de notícias especializada, a ITAR-TASS, ou apenas TASS, de caráter estatal. Possui, ainda, agências de notícias tradicionais em conglomerados, como a estatal RIA Novolsti, ou a RT, ou agências menores, como a Sputnik.

A China possui uma grande agência própria nacional, de caráter estatal, a agência Xinhua, que mantém contratos com agências estrangeiras que atuam no país. 
A Xinhua também regula a entrada de informação dos veículos estrangeiros na potência asiática, o que já foi motivo de conflitos com outras agências, inclusive com a Reuters, quando esta pretendia publicar conteúdos na China (AGUIAR, 2016). A China possui, ainda, agências estatais menores, ou parte de conglomerados como a CCTV+, ou especializadas em produzir conteúdo para o exterior, como a China News Service, ou CNS.

A Índia rompeu a lógica tradicional das agências de notícias estrangeiras com entrada nos países e criou suas agências para produção e difusão de conteúdo. O país rompeu a sua própria lógica interna, uma vez que o capital estrangeiro tinha forte presença por meio da Reuters (AGUIAR, 2016). Destaca-se que, na Índia, as negociaçóes entre empresários locais e a Reuters, que tinha presença no país com sucursal própria desde 1905, tiveram um papel importante para essa transição.

Aguiar (2016) aponta que, em 1947, com a independência do país, o modelo comunicacional vigente, dependente de potências externas, já não via mais tanta sustentação, uma vez que a Reuters, uma agência inglesa, mantinha até então o monopólio no território indiano com a Associated Press of India (API). Como a Índia buscava se desvencilhar das principais amarras colonialistas e alavancar sua independência política, foi criada a Press Trust of India, PTI, em 1949, tornando-se efetivamente independente da Reuters em 1953. Embora tenha passado por diversas mudanças desde então, atualmente continua sendo uma empresa organizada enquanto associação oficialmente sem fins lucrativos, de caráter nacional, que permite relativa autonomia.

O Brasil carece de regulação de mídia. Aqui se tem a livre entrada e circulação de conteúdo, inclusive os de agências internacionais, que refletem interesses próprios, os quais podem ser conflitantes com alguns interesses nacionais, e mesmo prejudicar o avanço do projeto integracionista e a visão sobre ele, como será avaliado mais adiante. Percebe-se como o discurso estrangeiro pauta o nacional, sendo que o primeiro náo tem o compromisso social com a realidade e as particularidades do contexto nacional ou regional.

Assinala-se que o fluxo e o acesso à informação são aspectos essenciais quando se aborda o direito à comunicação; contudo, precisa-se discutir a forma como isso está sendo feito e abrir caminhos para que outras iniciativas comunicacionais tenham espaço de atuação, consigam ter concessóes de canais e espectro radiofônico. Desse modo, a sociedade poderá ter acesso ao conteúdo jornalístico e informativo de maneira mais plural, que não reproduza apenas interesses das elites, de grandes 
214 | Beatriz Soares Bidarra, Jéssica Maria Grassi e Lucas Kerr Oliveira

monopólios comunicacionais ou de meios internacionais que relatam a nossa realidade sob a ótica externa de países hegemônicos.

Para que isso ocorra, portanto, é necessário vontade política para que iniciativas de democratização da comunicação se concretizem de fato, uma vez que nem pautar o assunto na agenda pública tem sido efetivado. Essa crítica é recorrente quando se coloca em pauta a regulação da mídia, especialmente no Brasil. O que ocorre é que os grandes monopólios midiáticos que sempre coordenaram o campo comunicacional no país não demostram grande interesse em democratizar esse acesso.

\section{A Unasul e a institucionalização da América do Sul como região geopolitica: origens, objetivos e desafios atuais}

Para compreender as origens da União das Nações Sul-Americanas, deve-se levar em consideração o papel da Primeira Reunião de Presidentes Sul-Americanos, realizada em Brasília, em 2000. Foi nessa ocasião que, pela primeira vez, reuniram-se os 12 Chefes de Estado da América do Sul, os quais conceberam o impulso a ser dado à integração regional de modo a torná-la mais abrangente, transcendendo questões econômicas e comerciais, ênfase dada até então no subcontinente, e englobando a cooperação política e social, buscando promover o desenvolvimento autônomo e a melhor inserção da América do Sul no cenário internacional (VIZENTINI, 2003; GUIMARÃES, 2007; PADULA, 2010).

O primeiro resultado dessas conversações foi a formulação da iniciativa para a Integração da Infraestrutura Regional Sul-Americana (IIRSA), formalizada em 2002. A iniciativa tinha como propósito promover a integração física da região, com base na construção de infraestrutura de transporte, telecomunicações e energia. Nesse sentido, a IIRSA é considerada o embrião do processo que culminou na criação da Unasul, sendo que, em 2009, foi incorporada ao Conselho Sul-Americano de Infraestrutura e Planejamento (Cosiplan) no âmbito da Unasul (PADULA, 2010; COSTA, 2011; HONÓRIO, 2013; JAEGER, 2014).

Com o avanço do diálogo, em 2004, na III Reunião dos Presidentes SulAmericanos, os representantes buscaram empenhar-se na proposta defendida em 2000, expandindo a integração regional com a formação da Comunidade SulAmericana de Nações (CASA/CSN). A CASA pretendia criar um espaço de cooperação e integração unindo o Mercado Comum do Sul (Mercosul) e a Comunidade Andina de Naçôes (CAN). Entre os temas prioritários de sua agenda destacam-se: diálogo político, integração física, meio-ambiente, integração energética, 
mecanismos financeiros, assimetrias, promoção da coesão social, da inclusão social e da justiça social (PAGLIARI, 2009; GRANATO, 2015).

A CASA foi substituída em 2008, quando os presidentes dos 12 países sulamericanos aprovaram o Tratado Constitutivo da Unasul. A Unasul conta com 12 Conselhos Ministeriais e Setoriais, agregando em sua agenda temas como segurança e defesa, infraestrutura, energia, telecomunicaçôes, a preocupação com os direitos humanos e a democracia e o desenvolvimento socioeconômico, abordando questóes relacionadas à educação, saúde, ciência e tecnologia, cultura e a preocupação acerca do crime organizado e das drogas na regiáo.

O conjunto de articulaçóes e iniciativas no subcontinente nesse período o promoveram à uma região geopolítica, ou seja, a “[...] uma entidade política transnacional dotada de unidade mínima e arcabouço institucional baseados em princípios e macro-objetivos comuns nas relaçôes internacionais" (COSTA, 2009, p. 7). Nesse sentido, a América do Sul existiria como objeto teórico e empírico de análise em termos geopolíticos, não cabendo à América Latina a mesma perspectiva (COSTA, 2009).

Apesar da sua importância no cenário regional, desde sua criação o bloco vem enfrentando diversos desafios. Entre eles, aponta-se o fato de ser esta uma região heterogênea e extremamente assimétrica, tornando os interesses de cada país e suas dificuldades significativamente distintas, assim como suas percepções de ameaças, o que faz com que surjam inúmeras dificuldades nas conversações e na busca pelo consenso, sobrepondo-se, assim, as divergências entre os membros. Ademais, são enumerados, também, entre as fraquezas da Unasul, os problemas resultantes das dificuldades de financiamento da organização, as fragilidades institucionais, as debilidades dos Estados e a conjuntura internacional desfavorável (MENA, 2013).

Diante desse cenário, e devido às crises internas dos países-membros, a crise na instituição veio se intensificando, principalmente nos últimos anos, com a onda neoliberal que permeia a América do Sul, observando-se o esvaziamento da agenda integracionista entre os países. A partir disso, o diálogo entre os membros foi se tornando difícil, o que se aprofundou no início de $2017 \mathrm{com}$ a saída de Ernesto Samper da Secretaria Geral da Unasul (BERRINGER, 2018).

Ressalta-se que o mandato do colombiano frente à Secretaria terminou em agosto de 2016 e, nessa ocasião, Samper expressou sua não intenção na renovação do cargo. Após sua notificação, os países membros da Unasul propuseram a extensão de seu mandato até 31 de janeiro de 2017, devido à necessidade de encontrar um 
substituto para o cargo por meio do consenso entre os países (UNASUL, 2016). No entanto, os líderes dos 12 países-membros náo lograram alcançar o consenso, e a Secretária Geral se encontrou sem um representante após janeiro de 2017. A partir de então, as reuniões passaram a ser menos frequentes e o diálogo entre os países foi seriamente afetado, atrasando decisóes e paralisando em grande medida o bloco (BERRINGER, 2018).

Passado mais de um ano nessa situaçáo, e sem a perspectiva de chegarem a uma solução consensual, em abril de 2018 (ano em que a Unasul completou dez anos de existência), seis países anunciaram a suspensão de suas atividades por tempo indeterminado - Argentina, Colômbia, Chile, Brasil, Paraguai e Peru - alegando a dificuldade de alcançar o consenso e o funcionamento inadequado da instituição. Destaca-se que esse anúncio não foi posto como um abandono ou desligamento definitivo, mas como suspensão temporária de suas participaçôes (SANAHUJA e COMINI, 2018; SPEKTOR, 2018).

Sanahuja e Comini (2018) propõem que esse comunicado era uma estratégia que visava pressionar os demais países a tomar uma decisão - principalmente em relação à Bolívia e à Venezuela, que vetaram o único candidato para o cargo, o argentino José Octávio Bordón. Além disso, essa decisão e a consequente paralisação da Unasul também podem ser justificadas pela agenda dos governos conservadores da "nova direita" sul-americana, que objetivaria desmantelar o legado dos governos progressistas da região e priorizar novamente a agenda econômico-comercial (SANAHUJA e COMINI, 2018).

Essa situação se manteve e, em agosto de 2018, a Colômbia anunciou sua retirada do bloco. Essa decisão foi justificada pelo não posicionamento da instituição frente às condições ditas brutais vivenciadas na Venezuela (CRISE..., 2018). O Presidente colombiano: “[...] criticou a Unasul por não ter denunciado os 'atropelos' do governo do venezuelano Nicolás Maduro e que o bloco não exerceu o dever de garantir que essas açóes do regime chavista constituíssem a eliminação da liberdade dos cidadãos" (CRISE..., 2018).

Essa situação de desmantelamento do projeto integracionista formulado no início dos anos 2000 foi se tornando mais crítica e aprofundando-se com o não entendimento entre os países. Sendo assim, em março de 2019, o Equador, país-sede da organização, também anunciou sua saída e requereu a devolução do prédio sede da Secretaria Geral da Unasul, localizada em Quito (EQUADOR..., 2019; VALENCIA e LLANGARI, 2019). Da mesma forma, Peru, Paraguai e Brasil anunciaram sua 
retirada do bloco (BRASIL..., 2019). E, mais tarde, em junho, o Chile também denunciou o Tratado Constitutivo da Unasul (CHILE..., 2019).

Além disso, surgiu uma proposta para substituir a organização, a qual foi denominada Fórum para o Progresso da América do Sul (PROSUR), rompendo com os avanços feitos até então pelos governos progressistas na regiáo. Sobre isso, na Declaração Presidencial sobre Renovação e Fortalecimento da Integração na América do Sul, firmada pela Argentina, Brasil, Chile, Colômbia, Equador, Guiana, Paraguai e Peru, os países propuseram:

(i) que este espaço deverá ser implementado gradualmente, ter estrutura flexível, leve, que não seja custosa, com regras de funcionamento claras e com mecanismo ágil de tomada de decisóes; (ii) que este espaço abordará de maneira flexível e com caráter prioritário temas de integração em matéria de infraestrutura, energia, saúde, defesa, segurança e combate ao crime, prevenção de e resposta a desastres naturais; (iii) que os requisitos essenciais para participar deste espaço serão a plena vigência da democracia e das respectivas ordens constitucionais, o respeito ao princípio de separação dos poderes do estado, e a promoção, proteção, respeito e garantia dos direitos humanos e das liberdades fundamentais, assim como a soberania e a integridade territorial dos estados, em respeito ao direito internacional (BRASIL, 2019).

A crise na Unasul, provocada por todas as questóes destacadas foi amplamente divulgada pelas mídias internacionais. Nesse sentido, a próxima seção analisará como se deu a veiculação dessas notícias, enfatizando o posicionamento de duas das maiores agências internacionais de notícias, a Reuters e a EFE.

\section{Análise das noticias sobre a crise da Unasul veiculadas pelas agências Reuters e EFE}

A análise proposta neste estudo está em grande parte alicerçada nos conceitos de Laurence Bardin (1977) no que se refere à análise de conteúdo. A autora, ao conceituar o método, deixa claro quais procedimentos pertencentes a essa metodologia devem ser adotados a fim de se retirar o que se deseja de seu objeto. A análise de conteúdo, para ela, consiste em:

[...] um conjunto de técnicas de análise das comunicações visando obter, por procedimentos, sistemáticos, objetivos de descrição do conteúdo das mensagens, indicadores (quantitativos ou náo) que permitam a inferência 
de conhecimentos relativos às condiçốes de produção/ recepção (variáveis inferidas) destas mensagens. (BARDIN, 1977, p. 42).

Durante a análise de conteúdo desenvolvida, no processo de categorização, foram utilizados dois conceitos da área de comunicação para embasar a análise, o agendamento e o enquadramento. $\mathrm{O}$ enquadramento, defendido por Erving Goffman (1986), e Newsmaking, por Gaye Tuchman (1978), partem da premissa de que as notícias são consideradas uma construção da realidade, a qual é retratada pelos veículos de comunicação. Nessa perspectiva, ressalta-se que o enquadramento diz respeito a quais assuntos são destacados ou levados a público. Seguiu-se alguns elementos metodológicos de Entmann (1993) procurando verificar que quadros de sentidos estavam sendo formados quando se falava de Unasul nos meios de comunicação em análise, considerando que essa formação de sentidos pode ser realizada por meio de elementos textuais e/ou imagéticos que compóem a veiculação das notícias.

Quanto ao agendamento, este se refere ao que é colocado na agenda pública para discussão (COLLING, 2002). Em resumo, o agendamento refere-se ao que a mídia faz com que entre na agenda pública, e o enquadramento traduz-se em como os assuntos são tratados pela mídia, ainda que inseridos em um grande tema, que, neste caso, é a Unasul. Para que se chegasse às categorias finais do estudo, foi realizada uma pré-análise das notícias previamente filtradas pela palavra-chave Unasul no ambiente digital das duas agências.

Os conceitos de agendamento e enquadramento possuem alguns parâmetros fundamentais para o entendimento do conteúdo jornalístico veiculado. Sobre isso, McCombs (2009) enfatiza que:

[...] a convergência do agendamento dos atributos com o conceito de enquadramento oferece novos entendimentos sobre a influência mantida por vários padróes de atributos encontrados nas notícias de como o público pensa sobre os temas públicos. Estas influências no público incluem um amplo conjunto de atributos descrevendo os vários aspectos de um objeto, atributos específicos que definem enquadramentos dominantes, e atributos específicos que funcionam como argumentos marcantes. (MCCOMBS, 2009, p. 151).

Após a análise do conteúdo, as inferências de dados são possíveis quando analisado o enquadramento conferido às notícias (GOFFMAN, 1986). Para tanto, a análise quanti-qualitativa observará algumas categorias: cooperação/diálogo; 
inatividade do bloco (estagnação), dificuldade de consenso; ineficiência/inoperância. Essas categorias foram selecionadas a partir da leitura, visualização e pré-análise dos principais temas e enfoques abordados nas notícias analisadas.

O quadro 1 apresenta a relação das notícias utilizadas para este estudo.

Quadro 1 - Notícias da Reuters e da EFE analisadas no estudo

\begin{tabular}{|c|c|c|c|}
\hline $\mathrm{N}^{\circ}$ & Manchete & Data & Referência \\
\hline \multicolumn{4}{|c|}{ Reuters } \\
\hline 01 & Colômbia anuncia que deixará a Unasul em 6 meses. & 28 ago. 2018 & $\begin{array}{l}\text { Bocanegra } \\
(2018)\end{array}$ \\
\hline 02 & $\begin{array}{l}\text { Colombia's President Duque says will whitdraw from Unasur } \\
\text { bloc. }\end{array}$ & 27 ago. 2018 & $\begin{array}{l}\text { Murfhy } \\
(2018)\end{array}$ \\
\hline 03 & Brasil e outros 5 países suspendem participação na Unasul. & 20 abr. 2018 & $\begin{array}{l}\text { Paraguassu } \\
(2018)\end{array}$ \\
\hline 04 & $\begin{array}{l}\text { Argentina, Brasil, Chile, Colombia, Paraguay y Perú } \\
\text { suspenden participación en bloque Unasur. }\end{array}$ & 20 abr. 2018. & $\begin{array}{l}\text { Paraguassu e } \\
\text { Desantis } \\
(2018)\end{array}$ \\
\hline \multicolumn{4}{|c|}{ EFE - Edição Brasil } \\
\hline 05 & Brasil e outros 5 países suspendem atividades na Unasul. & 21 abr. 2018 & $\begin{array}{l}\text { Brasil... } \\
(2018 b)\end{array}$ \\
\hline 06 & Chanceler do Equador advoga pela Unasul em visita ao Brasil. & 17 ago. 2018 & $\begin{array}{l}\text { Chanceler... } \\
\text { (2018) }\end{array}$ \\
\hline 07 & $\begin{array}{l}\text { Colômbia anuncia que cumprirá promessa de Duque de se } \\
\text { retirar da Unasul. }\end{array}$ & 10 ago. 2018 & $\begin{array}{l}\text { Colômbia... } \\
\text { (2018) }\end{array}$ \\
\hline 08 & $\begin{array}{l}\text { Paraguai vê como necessário "redirecionar" objetivos da } \\
\text { Unasul em crise. }\end{array}$ & 23 abr. 2018 & $\begin{array}{l}\text { Paraguai... } \\
(2018)\end{array}$ \\
\hline 09 & $\begin{array}{l}\text { Parlamento da Unasul na Bolívia recebe críticas por alto custo } \\
\text { e inutilidade. }\end{array}$ & 13 set. 2018 & $\begin{array}{l}\text { Parlamento... } \\
(2018)\end{array}$ \\
\hline \multicolumn{4}{|c|}{ EFE - Edição América } \\
\hline 10 & $\begin{array}{l}\text { Bolivia desconoce si hay intenciones de algunos países de dejar } \\
\text { la Unasur y prevé una reunión en mayo. }\end{array}$ & 20 abr. 2018 & $\begin{array}{l}\text { Bolivia... } \\
\text { (2018a) }\end{array}$ \\
\hline 11 & $\begin{array}{l}\text { Bolivia pide a Colombia "reflexionar" su decisión de retiro de } \\
\text { la Unasur. }\end{array}$ & 12 ago. 2018 & $\begin{array}{l}\text { Bolivia... } \\
(2018 \mathrm{~b})\end{array}$ \\
\hline 12 & $\begin{array}{l}\text { Brasil aboga en Bolivia por el diálogo para superar los } \\
\text { "impases" en la Unasur. }\end{array}$ & 20 ago. 2018 & $\begin{array}{l}\text { Brasil... } \\
(2018 \mathrm{a})\end{array}$ \\
\hline
\end{tabular}




\begin{tabular}{|c|c|c|c|}
\hline 13 & $\begin{array}{l}\text { Canciller chileno: Unasur no logró sus fines y está en un } \\
\text { "deplorable estado". }\end{array}$ & 27 abr. 2018 & $\begin{array}{l}\text { Canciller... } \\
(2018)\end{array}$ \\
\hline 14 & $\begin{array}{l}\text { Chile dice que en el escenario regional actual la Unasur "no } \\
\text { conduce a nada". }\end{array}$ & 23 abr. 2018 & $\begin{array}{l}\text { Chile... } \\
(2018)\end{array}$ \\
\hline 15 & $\begin{array}{l}\text { Colombia da un giro a su política exterior y se retira de la } \\
\text { Unasur. }\end{array}$ & 10 ago. 2018 & $\begin{array}{l}\text { Colombia... } \\
(2018 \mathrm{a})\end{array}$ \\
\hline 16 & $\begin{array}{l}\text { Colombia notifica a la Unasur que deja el bloque por no } \\
\text { denunciar la crisis venezolana. }\end{array}$ & 28 ago. 2018 & $\begin{array}{l}\text { Colombia... } \\
(2018 b)\end{array}$ \\
\hline 17 & $\begin{array}{l}\text { Copppal cree que el retiro de los países de la Unasur responde } \\
\text { a la "estrategia" de EE.UU. }\end{array}$ & 24 abr. 2018 & $\begin{array}{l}\text { Copppal } \\
(2018)\end{array}$ \\
\hline 18 & $\begin{array}{l}\text { Ecuador apela al diálogo y la unidad para resolver la crisis en } \\
\text { Unasur. }\end{array}$ & 22 abr. 2018 & $\begin{array}{l}\text { Ecuador... } \\
(2018)\end{array}$ \\
\hline 19 & $\begin{array}{l}\text { El canciller de Bolivia confirma la recepción de carta y apela al } \\
\text { diálogo en Unasur. }\end{array}$ & 20 abr. 2018 & $\begin{array}{l}\text { El canciller... } \\
(2018 \mathrm{a})\end{array}$ \\
\hline 20 & $\begin{array}{l}\text { El canciller paraguayo señala la "crisis" en la Unasur por su } \\
\text { viraje ideológico. }\end{array}$ & 17 ago. 2018 & $\begin{array}{l}\text { El canciller... } \\
(2018 b)\end{array}$ \\
\hline 21 & $\begin{array}{l}\text { El Kirchnerismo cuestiona que Argentina suspenda su } \\
\text { participación en la Unasur. }\end{array}$ & 21 abr. 2018 & $\begin{array}{l}\text { El } \\
\text { Kirchnerismo } \\
(2018)\end{array}$ \\
\hline 22 & $\begin{array}{l}\text { El presidente de Ecuador convertirá la sede de la Unasur en } \\
\text { Quito en una universidad indígena. }\end{array}$ & 06 jul. 2018 & $\begin{array}{l}\text { El presidente } \\
(2018 \mathrm{a})\end{array}$ \\
\hline 23 & $\begin{array}{l}\text { El presidente de Ecuador cree que la sede de UNASUR es "un } \\
\text { nuevo elefante blanco". }\end{array}$ & 06 jul. 2018 & $\begin{array}{l}\text { El presidente } \\
(2018 \mathrm{~b})\end{array}$ \\
\hline 24 & $\begin{array}{l}\text { El retiro de Colombia de la Unasur refleja el mal momento en } \\
\text { la integración, dice Uruguay. }\end{array}$ & 30 ago. 2018 & $\begin{array}{l}\text { El retiro } \\
(2018)\end{array}$ \\
\hline 25 & $\begin{array}{l}\text { Excanciller de Bolivia dice que Unasur y Alba tienen que } \\
\text { "seguir caminando". }\end{array}$ & 28 ago. 2018 & $\begin{array}{l}\text { Excanciller... } \\
(2018)\end{array}$ \\
\hline 26 & $\begin{array}{l}\text { Morales dice que se harán todos los esfuerzos para resolver la } \\
\text { crisis en Unasur. }\end{array}$ & 24 abr. 2018 & $\begin{array}{l}\text { Morales... } \\
(2018 \mathrm{a})\end{array}$ \\
\hline 27 & $\begin{array}{l}\text { Morales lanza un llamado a la integración para superar crisis } \\
\text { en Suramérica. }\end{array}$ & 05 set. 2018 & $\begin{array}{l}\text { Morales... } \\
(2018 b)\end{array}$ \\
\hline 28 & $\begin{array}{l}\text { Maduro pide "consciencia suramericana" a los países que } \\
\text { abandonan Unasur. }\end{array}$ & 21 abr. 2018 & $\begin{array}{l}\text { Maduro... } \\
(2018)\end{array}$ \\
\hline 29 & $\begin{array}{l}\text { Morales plantea el relanzamiento de la Unasur bajo el modelo } \\
\text { de la Unión Europea. }\end{array}$ & 18 abr. 2018 & $\begin{array}{l}\text { Morales... } \\
(2018 \mathrm{c})\end{array}$ \\
\hline 30 & $\begin{array}{l}\text { Preocupa a Parlasur decisión de } 6 \text { países de suspender } \\
\text { participación en Unasur. }\end{array}$ & 28 abr. 2018 & $\begin{array}{l}\text { Preocupa... } \\
(2018)\end{array}$ \\
\hline
\end{tabular}




\begin{tabular}{|l|l|l|l|}
\hline 31 & $\begin{array}{l}\text { Seis países de la Unasur anuncian que dejarán de participar en } \\
\text { ese bloque. }\end{array}$ & 20 abr. 2018 & Seis... (2018) \\
\hline 32 & $\begin{array}{l}\text { Uruguay se mantiene en la Unasur pese a que sus vecinos le } \\
\text { dan la espalda. }\end{array}$ & 24 abr. 2018 & $\begin{array}{l}\text { Uruguay... } \\
(2018 a)\end{array}$ \\
\hline 33 & "Uruguay no piensa salirse de la Unasur", asegura el canciller. & 21 abr. 2018 & $\begin{array}{l}\text { Uruguay... } \\
(2018 b)\end{array}$ \\
\hline
\end{tabular}

Fonte: Elaborado pelos autores.

Desse modo, foram analisadas 33 notícias, priorizando o período entre abril e agosto de 2018, período de marcante desmanche da Unasul que compreendeu o anúncio da suspensão das atividades de seis países (Argentina, Colômbia, Chile, Brasil, Paraguai e Peru), bem como o anúncio da retirada da Colômbia - primeiro país a fazer essa declaração - do bloco em um prazo de seis meses. Assim, são feitas três divisões para a análise aqui proposta: primeiro será abordado o conteúdo das notícias a partir das categorias selecionadas; após, serão exploradas as fontes ouvidas nessas notícias; e, por fim, serão examinadas as manchetes das notícias veiculadas pela Reuters e pela EFE.

\section{O conteúdo das notícias e as categorias de análise propostas}

Observa-se que, nas notícias veiculadas pela britânica Reuters, a paralisia ou estagnação da Unasul é enfatizada, assim como menções à falta de consenso e mau funcionamento da organização são frequentes, inclusive apontando para uma situação de "acefalia" do bloco.

Ao citar a carta escrita pelos seis Estados-membros, por exemplo, a agência britânica destaca a "alarmante situação de indisciplina" apontada pelos países desde a saída do Secretário Geral, em 2017 (PARAGUASSU e DESANTIS, 2018), e que os seis países tratam de "[...] um 'conjunto de problemas relacionados ao funcionamento da organização' mas, principalmente da situação de 'acefalia' do bloco" (PARAGUASSU, 2018).

A Reuters traz também a declaração de uma fonte do Ministério das Relações Exteriores do Peru que pondera que "[...] a Unasul funciona por meio de consenso e dentro de Unasul há tais discrepâncias entre os membros sobre as visões políticas e econômicas que a torna inoperante", e acrescenta que "[...] é bem difícil chegar a um consenso quando há diferenças de opiniões tão marcadas... está implícito que este mecanismo já não tem sentido". Ademais, “[...] como não resolve nada, [a Unasul] 
acaba sendo um gasto supérfluo, pagando cotas por uma coisa que não serve" (PARAGUASSU, 2018).

Há também a citação da declaração do Presidente colombiano, Iván Duque, que afirma: "Não podemos continuar sendo parte de uma instituição que tem sido a maior cúmplice da ditadura da Venezuela" (BOCANEGRA, 2018).

Desse modo, por um lado, as notícias veiculadas pela Reuters reforçam o discurso do mau funcionamento do bloco e, por outro, a pouca atençáo dada à cobertura da situação em comparação com a EFE é ponto relevante a se considerar na primeira agência foram encontradas apenas 4 notícias ${ }^{2}$ sobre o tema, enquanto na segunda foram 29 no mesmo período 3 .

A ausência do tema na veiculação de notícias, por vezes, é um fator mais importante de se analisar do que a presença desses temas. Há, sobretudo, um silenciamento do assunto na agenda pública, o que contribui para certa distorção da realidade e distanciamento do problema, fazendo parecer que nada está acontecendo na região e com o bloco.

Em comparação, a EFE, agência de notícias espanhola, confere maior visibilidade ao tema, abordando reiteradamente em suas notícias a falta de consenso como elemento recorrente enfrentado pela Unasul, bem como o funcionamento inadequado da organização. Ademais, destaca-se a necessidade de mudanças, apontando a Unasul como bloco inoperante e sem resultados concretos, além de ressaltar a grave situação em que se encontra a organização.

Apesar disso, algumas notícias retratam o apelo ao diálogo, à unidade e à consciência sul-americana. Com relação aos discursos mais favoráveis ou com maior neutralidade em relação à Unasul, destaca-se, em algumas notícias da EFE, o posicionamento de alguns chanceleres e presidentes, como do Equador, da Bolívia e do Uruguai, que convergem para o diálogo, clamando a unidade das naçõesmembros, enfatizando inclusive pontos positivos da integração e a necessidade de fortalecimento da entidade.

\footnotetext{
${ }^{2}$ As notícias encontradas em português também foram encontradas em ediçóes no idioma espanhol e inglês.

${ }^{3}$ Ressalta-se que não se pode mensurar a quantidade de notícias sobre a crise da Unasul em relação ao total de notícias das agências neste período, uma vez que as pesquisas feitas nos sites das agências tiveram que ser refinadas por tema - neste caso, utilizou-se a palavra-chave "Unasul". O que se pode afirmar é que, no período analisado, todas as notícias efetivamente relacionadas à Unasul nos sites de ambas as agências eram sobre a crise mencionada.
} 
Sobre isso, destaca-se, por exemplo, o boletim divulgado pelo Ministério das Relaçóes Exteriores da Bolívia, que é mencionado em uma das notícias da EFE analisadas. Nele, cita-se que a "[...] Unasul é o espaço natural de integração que constitui o sinal de identidade dos povos do sul, porque estamos unidos por nossa história e pela Mãe Terra, porque somos Unasul"‘ (BOLIVIA..., 2018b, tradução nossa). No mesmo sentido, está a declaração do ex-Ministro de Relações Exteriores da Bolívia, David Choquehuanca: "Eu vejo com muita preocupação e tristeza algumas atitudes de alguns líderes, de algumas autoridades que querem caminhar contra o que nossos povos querem. Nossos povos querem integração, a integração traz grandes benefícios para nossos povos"s (EXCANCILLER..., 2018, tradução nossa).

Da mesma forma, é citada em outra notícia a declaração do chanceler José Valencia, do Equador. O equatoriano falou ao chanceler brasileiro, Aloysio Nunes, que "[...] a Unasul é uma experiência útil para nos integrar" e que "[...] no Equador acreditamos que a forma de buscar uma saída é se concentrar em tudo aquilo que nos une" (CHANCELER..., 2018). A mesma notícia aponta também que o chanceler pediu por um esforço diplomático em prol da Unasul.

Outro exemplo é a manifestação do vice-chanceler do Uruguai, citada pela $\mathrm{EFE}$, em que ele diz que a integração regional não está passando por um bom momento, mas que este não deve ser um motivo para “[...] renunciar ao projeto e ao processo integracionista, mas que tem-se que buscar 'formas para fortalecer e revigorar' a integração"' (EL RETIRO..., 2018, tradução nossa). Ademais, aponta-se o pedido do Presidente boliviano, Evo Morales: "Quero pedir aos irmãos presidentes da América do Sul e em especial aos nossos movimentos sociais, é nossa obrigação fortalecer e relançar nossa Unasul"’ (MORALES..., 2018c, tradução nossa).

\footnotetext{
4 "Unasur es el espacio natural de integración que constituye la seńa de identidad de los pueblos del sur, porque estamos unidos por nuestra historia y por la Madre Tierra, porque somos Unasur" (BOLIVIA..., 2018b).

5 "Yo veo con mucha preocupación y tristeza algunas actitudes de algunos líderes, de algunas autoridades que quieren caminar en contra de lo que quieren nuestros pueblos. Nuestros pueblos quieren integración, la integración trae grandes beneficios a nuestros pueblos" (EXCANCILLER..., 2018).

6 "[... [ renunciar al proyecto y al proceso integrador sino que tienen que buscar 'formas para fortalecer y revigorizar' a la integración" (EL RETIRO..., 2018).

7 "Quiero pedir a los hermanos presidentes de Suramérica y en especial a nuestros movimientos sociales, es nuestra obligación fortalecer y cómo relanzar nuestra Unasur” (MORALES..., 2018c).
} 
Embora esses aspectos sejam aparentes, a quantidade de notícias que traz esse posicionamento à tona é baixa, no máximo 11 dentre as 29 notícias da EFE. Ademais, mesmo nas notícias que ressaltam a importância da integração, frequentemente apontam-se as dificuldades, o funcionamento inadequado da Unasul ou a grave situação em que se encontra a organização.

A seguir, a Tabela 1 faz uma síntese das menções de cada uma das categorias de análise selecionadas neste estudo. As categorias foram formadas em uma préanálise das notícias, observando a predominância de alguns aspectos que pudessem ser enquadrados em uma mesma variável. Essas categorias foram relacionadas pelo fato de haver citaçóes no corpo do texto de cada reportagem. A categoria "cooperação/diálogo", por exemplo, faz referência ao número de vezes que os termos foram citados nos textos jornalísticos.

Tabela 1 - Quantidade de aparições das categorias de análise selecionadas

\begin{tabular}{|c|c|c|c|c|c|}
\hline Categorias & $\begin{array}{l}\text { Número } \\
\text { total de } \\
\text { citaçóes em } \\
33 \text { notícias } \\
\text { analisadas }\end{array}$ & $\begin{array}{l}\text { Número de } \\
\text { citaçóes em } \\
4 \text { notícias da } \\
\text { Reuters }\end{array}$ & $\%$ & $\begin{array}{l}\text { Número de } \\
\text { apariçóes em } \\
29 \text { notícias } \\
\text { da EFE }\end{array}$ & $\%$ \\
\hline Cooperação/ diálogo & 5 & 0 & 0 & 5 & $15,15 \%$ \\
\hline $\begin{array}{l}\text { Inatividade (estagnação) } \\
\text { do bloco }\end{array}$ & 12 & 2 & $6,06 \%$ & 10 & $30,30 \%$ \\
\hline $\begin{array}{l}\text { Dificuldade/Falta de } \\
\text { consenso }\end{array}$ & 10 & 2 & $6,06 \%$ & 8 & $24,24 \%$ \\
\hline Ineficiência/Inoperância & 6 & 2 & $6,06 \%$ & 4 & $12,12 \%$ \\
\hline \multicolumn{2}{|c|}{$\begin{array}{l}\text { Total de citaçóes em } 4 \text { notícias da } \\
\text { Reuters }\end{array}$} & \multicolumn{3}{|l|}{06} & $18,18 \%$ \\
\hline \multicolumn{2}{|c|}{ Total de citações em 29 notícias da EFE } & \multicolumn{3}{|l|}{27} & $81,81 \%$ \\
\hline \multicolumn{2}{|l|}{ Total de citaçóes } & \multicolumn{3}{|l|}{33} & \\
\hline \multicolumn{2}{|l|}{ Total de notícias analisadas } & \multicolumn{3}{|l|}{33} & \\
\hline
\end{tabular}

Fonte: Elaborado pelos autores. 
Tendo explorado o conteúdo e as variáveis presentes no corpo do texto, no tópico seguinte faz-se uma análise crítica acerca das fontes consultadas nas reportagens selecionadas para, em seguida, dar ênfase às manchetes dessas notícias.

\section{Fontes consultadas nas notícias e o lugar de fala da integração}

$\mathrm{Na}$ análise a que se propôs este trabalho, observou-se também quais fontes foram utilizadas pelas notícias quando retratado o tema da crise da Unasul. É perceptível a utilização de fontes oficiais, como representantes governamentais, do Ministério das Relações Exteriores e documentos oficiais dos países-membros do bloco.

A Agência Reuters, apesar de ter uma frequência menor de cobertura jornalística sobre o tema, por vezes utiliza-se de maior número de fontes e, em grande parte, fontes oficiais. Segundo Schmitz (2010), essas são as fontes preferidas dos jornalistas, pois emitem a informação ao cidadão e tratam do interesse público. Contudo, o autor ressalta que muitas vezes essas fontes podem falsear a realidade para preservar interesses de grupos políticos (SCHMITZ, 2010).

Há uma aparição ínfima de fonte testemunhal, que é aquela que relata o que viu e ouviu e não necessariamente está relacionada a algum cargo institucional ou político. Ao mesmo tempo, não se utiliza a fonte especializada, que é a pessoa com saber específico que analisa o tema de modo científico e/ou conjectural, o que já demonstra que, a despeito de serem agências de notícias distintas, a cobertura jornalística sobre o tema em muito se assemelha quando o tocante são as vozes ouvidas e utilizadas na produção da notícia.

A Reuters se utiliza predominantemente de fontes como chanceleres ou ministros de Relações Exteriores, vice-ministros, presidentes dos países membros do bloco e o documento oficial que anunciou a decisão dos países de suspender a participação na Unasul. Em alguns casos, utiliza-se de fontes não identificadas, categorizadas como sigilosas, tais como uma fonte de dentro do Ministério de Relações Exteriores.

Como exemplos das fontes consultadas pela Reuters, tem-se citações de declaraçôes do Presidente da Colômbia, Iván Duque, citaçôes da carta enviada pelos seis países comunicando a suspensão de suas atividades no bloco, declarações do chanceler da Bolívia - e Presidente pró-tempore do bloco - Fernando Huanacuni, do Ministro de Relaciones Exteriores do Uruguai, Rodolfo Novoa, e fontes não identificadas do Itamaraty e outras chancelarias. Salienta-se aqui que, em sua 
maioria, essas fontes utilizadas ressaltaram aspectos negativos em relação à situação e ao bloco - como os exemplos citados na seçáo anterior.

Quanto a EFE, nas 29 notícias analisadas, são observadas citaçóes da carta em que os seis países anunciaram a suspensão de suas atividades, das declaraçôes dos Ministros das Relações Exteriores do Paraguai (Eladio Loizaga), da Bolívia (Fernando Huanacuni), do Brasil (Aloysio Nunes Ferreira), do Equador (José Valencia), da Colômbia (Carlos Holmes Trujillo), do Uruguai (Rodolfo Nin Novoa); dos Presidentes da Colômbia (Iván Duque), da Bolívia (Evo Morales), do Equador (Lenín Moreno), da Venezuela (Nicolás Maduro); do Presidente da Conferencia Permanente de Partidos Políticos de América Latina y el Caribe (Copppal), Manolo Pichardo; dos deputados da Frente para la Victoria (FPV) - Partido Justicialista (PJ) - entre outros.

As citações mais frequentemente enfatizam aspectos negativos, como a declaração do chanceler colombiano Carlos Holmes Trujillo, para quem a Unasul era "[...] cúmplice da ditadura venezuelana" (COLÔMBIA..., 2018). Outras ressaltam a necessidade de mudança interna da organização, como a do chanceler paraguaio, que acredita na necessidade de "[...] redirecionar os objetivos da Unasul, [...] subtrair essa tendência de ideologizar que o nosso órgão sub-regional teve nos últimos anos" (PARAGUAI..., 2018). Mas também há mençôes de declaraçôes que apelam à cooperação e ao diálogo - como as mencionadas na seção anterior.

Tabela 2 - Quantidade de apariçóes das categorias de análise de fontes

\begin{tabular}{c|c|c|c|c}
\hline Categorias das Fontes & $\begin{array}{c}\text { Número de citaçóes } \\
\text { em 4 notícias da } \\
\text { Reuters }\end{array}$ & $\mathbf{\%}$ & $\begin{array}{c}\text { Número } \\
\text { citaçóes em 29 } \\
\text { notícias da EFE }\end{array}$ & $\%$ \\
\hline Oficial identificada & 07 & $15,90 \%$ & 34 & $77,27 \%$ \\
\hline Oficial sigilosa & 02 & $4,54 \%$ & 0 & 0 \\
\hline Especializada & 0 & 0 & 01 & $2,27 \%$ \\
\hline Testemunhal & 0 & 0 & 0 \\
\hline $\begin{array}{c}\text { Número total de } \\
\text { apariçóes de fontes }\end{array}$ & \multicolumn{4}{|}{44 citaçóes } \\
\hline
\end{tabular}

Fonte: Elaborado pelos autores. 
O que se pode inferir com a análise das fontes utilizadas é que as agências de notícias pautam a Unasul, sua situação, dificuldades enfrentadas, e utilizam documentos e autoridades, mas não buscam aprofundar mais a temática ouvindo especialistas ou pesquisadores da área. Ademais, o lugar de fala da integração regional é muito aquém do desejado para a difusão de conteúdo comunicacional mais isento.

O não silenciamento midiático sobre o bloco, e o que se está enfrentando para manter um processo de integração ativo, é de fato importante para, ao menos, visibilizar o tema na agenda pública. No entanto, observa-se que não há um esforço para uma cobertura mais ampla, do ponto de vista das vozes ouvidas para trabalhar algum tema ou situação quando o assunto é pautado. $\mathrm{Ou}$, pensando por outra via de análise, pode até haver um esforço reverso, em que se dá visibilidade ao tema, mas de forma unilateral, apenas sob o viés das fontes oficiais e ressaltando questôes negativas, que não contribuem para a compreensão do processo integracionista.

\section{As manchetes das noticias: chamadas para o distanciamento da integração}

Diante das notícias analisadas, é possível observar o enfoque de manchetes sobre questôes como os graves impasses entre os países e o alto custo e a inutilidade ou ineficácia do bloco, que tenderia a não levar os países-membros a lugar nenhum. Nessa perspectiva, citam-se aqui algumas manchetes da EFE: "Canciller chileno: Unasur no logró sus fines y está en un 'deplorable estado"; "Chile dice que en el escenario regional actual la Unasur 'no conduce a nada"; "Parlamento da Unasul na Bolívia recebe críticas por alto custo e inutilidade"; "El presidente de Ecuador cree que la sede de Unasur es 'un nuevo elefante blanco"; "Uruguay se mantiene en la Unasur pese a que sus vecinos le dan la espalda”.

Outras manchetes demonstram - poderíamos dizer que de forma mais sutil a crise ou abandono vivido pela Unasul: "El presidente de Ecuador convertirá la sede de la Unasur en Quito en una universidad indígena"; "Paraguai vê como necessário 'redirecionar' objetivos da Unasul em crise"; "Colômbia anuncia que cumprirá promessa de Duque de se retirar da Unasul”; "Colombia notifica a la Unasur que deja el bloque por no denunciar la crisis venezolana”.

Há também as manchetes que evidenciam a tentativa de diálogo e a permanência da cooperação: "Brasil aboga en Bolivia por el diálogo para superar los 'impases' en la Unasur"; “Morales dice que se harán todos los esfuerzos para resolver la crisis en Unasur"; "Ecuador apela al diálogo y la unidad para resolver la crisis en 
Unasur"; "El canciller de Bolivia confirma la recepción de carta y apela al diálogo en Unasur"; "Maduro pide 'consciencia suramericana' a los países que abandonan Unasur".

Por fim, há as manchetes - que, considera-se, de tom mais neutro - que apresentam o assunto sem adjetivar ou trazer suposiçóes. É o caso das quatro manchetes da Reuters; como exemplo, cita-se: "Brasil e outros 5 países suspendem participação na Unasul"; e "Colômbia anuncia que deixará a Unasul em 6 meses"; e de algumas da EFE, como: "Seis países de la Unasur anuncian que dejarán de participar en ese bloque"; e "Brasil e outros 5 países suspendem atividades na Unasul".

Importa esclarecer aqui que, de modo geral, as manchetes direcionam a leitura sobre o tema sob um viés crítico e, de certa forma, negativo, reforçando questôes como estagnaçáo, inoperância, grave crise, abandono à Unasul, bem como reforçam que o bloco não teve êxito em seu fim e está em condição deplorável.

Desta forma, o papel das manchetes no texto jornalístico é um aspecto importante a se refletir, uma vez que se constitui não só com um resumo do que vai tratar a notícia, mas também como um chamariz para que o leitor se interesse pelo tema, por um acontecimento pontual e por outros fatores que podem advir da abordagem que terá o fato ressignificado em notícia. Essa inclusive é uma das funçóes mais latentes do jornalismo online, da instantaneidade.

As características do webjornalismo, seja de maior flexibilidade com relação à estrutura textual, seja pela possibilidade de hiperlinkar um assunto tratado no texto para outra reportagem, abrem inúmeras possibilidades de complementar a informação que está sendo divulgada, a fim de que o leitor tenha acesso a um conteúdo mais robusto. Esses fatores, como trata Canavilhas (2006), podem trazer mudanças também nos títulos e na estrutura do texto, no sentido de não mais trazer de forma resumida a temática a que se prestará a tratar a matéria no título e subtítulo.

No conteúdo jornalístico analisado, observou-se, de modo geral, o reforço de informações negativas em relação à Unasul e da posição indiferente dos paísesmembros em relação à manutenção do órgão como mecanismo fundamental para pautar a integração latino-americana. Foi ressaltado o distanciamento do projeto integracionista regional e trazida uma percepção de falta de viabilidade em se concretizar algum avanço nesse sentido para os países sul-americanos, já que, da forma como são retratados, parecem nunca conseguir chegar a algum consenso.

É bem verdade que as assimetrias dos países que integram a entidade consistem em um desafio histórico de consolidação de um bloco regional, que 
também enfrenta dificuldades de financiamento próprio, sobretudo com a retomada de governos neoliberais na América do Sul que, por vezes, não veem integração regional como pauta prioritária para o desenvolvimento.

No entanto, não se pode negar os inúmeros avanços no que diz respeito ao importante papel da Unasul na prestação de serviços na regiấo, no apoio às iniciativas de cooperação e integração em temas até então não abordados na agenda integracionista regional, na gestão das crises regionais, na busca por soluções conjuntas e consensuadas nas diversas áreas nas quais a Unasul se inseriu como uma plataforma de diálogo entre todos os países sul-americanos, sem esquecer-se de seu papel na elevação da posição da América do Sul como uma região com maiores margens de autonomia e soberania no contexto internacional (SANAHUJA e COMINI, 2018; SPEKTOR, 2018).

Nessa perspectiva, deve-se sobrepor os pontos fortes da organização às suas fraquezas, uma vez que estes têm grande relevância ao se pensar o projeto de América do Sul. Entre esses elementos destacam-se também: sua população de aproximadamente 400 milhões de habitantes; sua superfície de cerca de 17 milhóes de quilômetros quadrados; seu PIB per capita de, aproximadamente, 12 mil dólares; a grande diversidade de recursos naturais; isso tudo colocaria a região como a quarta economia mundial devido à sua riqueza e crescimento econômico, assim como seu potencial geopolítico em se projetar internacionalmente (RAPOPORT e MADRID, 2011; MENA, 2013).

A atual implosão dos movimentos multilaterais na região pode ser observada a partir da nova onda neoliberal que tomou forma na América do Sul, mas também se deve atentar ao papel de atores externos, que perpetuam seus interesses na regiáo, e aos ataques internacionais, sejam eles velados, por meio de guerras híbridas, por exemplo, sejam eles mais escancarados. Defende-se que esse movimento mais recente, com a criação do Prosul, não representa um compromisso efetivo para a integraçáo voltada ao desenvolvimento da regiáo, principalmente no âmbito político e social, tal como se constatou, por exemplo, na primeira década do século XXI e com os governos progressistas na região.

Diante do cenário analisado neste artigo, pode-se perceber também o quanto o discurso da grande mídia pode ter impacto na agenda de discussão e no discurso formado no âmbito social a respeito da entidade. Nesse sentido, ressalta-se que os desafios da integração sul-americana são muito complexos, perpassam as diversidades culturais, as assimetrias entre os Estados, a situação política e econômica dos países do 
bloco, as divergências nas variadas áreas de cooperação e outras questôes amplamente discutidas no cenário sul-americano, e adentram também aspectos que podem não parecer tão evidentes à primeira vista.

\section{Considerações finais}

Esta pesquisa teve por objetivo investigar o discurso da grande mídia acerca dos processos de integração sul-americanos, analisando, para isso, o caso da crise da Unasul, com ênfase no período compreendido entre abril e agosto de 2018. A partir deste estudo, também se expôs como a mídia internacional, de certa maneira, exerce influência na agenda pública e, nesse caso, pode ter impacto, positivo ou negativo, na agenda integracionista para a região, na medida em que, na veiculação das notícias, define quais assuntos são interessantes de levar a público (agendamento) e de que forma o assunto deve ser pautado e que tipo de visáo sobre o tema ele pretende formar no leitor (enquadramento).

Foram examinadas, desse modo, 33 notícias veiculadas pela Reuters, agência privada britânica, e EFE, agência pública espanhola, analisando o teor dessas notícias, as manchetes, os pontos mais abordados e as fontes consultadas pelas agências, e investigando, assim, o aparente posicionamento dessas grandes agências internacionais frente ao contexto pelo qual vêm passando a Unasul e a integração sulamericana.

$\mathrm{Na}$ análise do conteúdo veiculado pelas agências de notícias selecionadas, observou-se que a EFE, por um lado, conseguiu aparentar um pouco mais de neutralidade se comparada com a Reuters - com as ressalvas que devem ser feitas de que, mesmo sendo agência pública, ela ainda sofre influência externa do capital privado, e as lógicas de produção jornalística não são por si só geradoras de conteúdos mais objetivos e próximos à neutralidade.

Pondera-se que a EFE dá maior visibilidade à Unasul e traz alguns aspectos favoráveis ao bloco, abordando a cooperação e certo diálogo e não enfocando somente a construção de uma realidade de estagnação e (quase) inutilidade da Unasul para os países. Assim, considera-se que a EFE apresenta uma cobertura mais neutra em relação à Unasul. Apesar disso, nas notícias analisadas, reiteradamente os apontamentos retomavam a dificuldade no diálogo e em alcançar o consenso, o não alinhamento dos próprios países-membros em levar o projeto da entidade adiante, a fragilidade e o funcionamento inadequado da organização.

A Reuters, por sua vez, utilizou palavras mais duras nas notícias sobre o bloco, mencionando, por exemplo, "grave crise", "acefalia", a Unasul como "gasto 
supérfluo" e algo "que não serve", destacando a ideia de estagnação ou inatividade do bloco, além de não mencionar a variável diálogo/cooperação em nenhuma das notícias analisadas. Deve-se ponderar, no entanto, que as manchetes dessa agência foram consideradas mais neutras em comparação com as da EFE, as quais se destacaram pelas adjetivaçóes e por trazer elementos de declarações feitas por autoridades - abrangendo tanto questóes positivas, como a questão do diálogo e da cooperação, quanto questóes negativas, como relativas aos altos custos, inutilidade e inoperância.

Ademais, se comparada com a EFE, a cobertura da Reuters sobre a temática é bem inferior -4 notícias apenas. Reitera-se que a ausência da veiculação dessas notícias deve ser considerada um fator importante, indicando um silenciamento do assunto na agenda pública, o que pode contribuir para a distorção da realidade e o distanciamento do problema, aparentando que nada está ocorrendo na região e com o bloco, ou mesmo que não é algo importante a ser discutido.

Desse modo, baseando-se na análise das notícias sobre a crise da Unasul veiculadas pelas duas agências, pode-se afirmar que, embora a objetividade seja um dos critérios de produção, no discurso da grande mídia internacional isso não se concretiza na prática.

Importa ressaltar que - como mencionado anteriormente, quando se trouxe o histórico da Unasul - desde a sua criação, o bloco já vinha enfrentando desafios e problemas internos, seja de falta de recursos econômicos, como de recursos humanos, questóes políticas e, não menos importante, de pressão externa. Porém, dez anos após sua criação, as tensões ou divergências entre os membros viraram pretextos para desmantelar uma importante organização de diálogo e autonomia regional. Esse desmanche do projeto integracionista na América do Sul pode ser relacionado à falta de políticas de Estado na regiáo, o que faz com que mudanças de governo - e as novas agendas destes -, como as vistas nos últimos anos, tenham impactos bruscos nos projetos regionais.

Os desafios para a construção de uma integração regional, em que pese a soberania e autonomia dos países do bloco frente às naçôes hegemônicas, são inúmeros (GUIMARÁES, 2007). No entanto, importa também pensar o papel da mídia que propaga discursos geopolíticos que possam interessar a determinados grupos detentores de capital financeiro e controladores de grandes conglomerados midiáticos. A cobertura midiática, a propagação da informação sem as barreiras estruturais que existiam anteriormente de telégrafo, submarino, tipografia, é um fator 
relevante a ser analisado periodicamente para mensurar e traçar caminhos possíveis para construir um outro discurso, favorável, sobre a necessidade de integração regional sul-americana desde a base. Essa análise, no entanto, requer um estudo mais aprofundado e pode instigar trabalhos futuros, uma vez que o objetivo central desta pesquisa se consistiu em analisar o discurso da mídia sobre a crise, compreendendo o que e como se falava quando um assunto como a Unasul era veiculado. $O$ papel da mídia como um fator para crise, como mencionado, mereceria um estudo mais aprofundado, bem como uma análise midiática de material jornalístico com recorte temporal maior, com criaçáo de um código de análise mais completo.

Por fim, a despeito das assimetrias culturais, econômicas, territoriais, a chance de desenvolvimento regional e a potencial inserção da região como uma potência de grande peso internacionalmente residem na força possível como bloco unido e consolidado. Ao contrário disso, a região permanecerá com as deficiências, estagnação e a dependência externa, além de continuar refém de políticas de governo que se interrompem em cada novo processo eleitoral.

- Beatriz Soares Bidarra é Mestra pelo Programa de PósGraduação em Integração Contemporânea da América Latina (PPGICAL) da Universidade Federal da Integração Latino-Americana (UNILA). Pesquisadora colaboradora do Núcleo de Estudos Estratégicos, Geopolítica e Integração Regional (NEEGI). E-mail: beatrizbidarra@gmail.com.

- Jéssica Maria Grassi é Doutoranda no Programa de PósGraduação em Relações Internacionais (PPGRI) da Universidade Federal de Santa Catarina (UFSC). Bolsista da CAPES. Pesquisadora no Grupo de Pesquisa em Estudos Estratégicos e Política Internacional Contemporânea (GEPPIC) e no Núcleo de Estudos Estratégicos, Geopolítica e Integração Regional (NEEGI). E-mail: jessica.grassi@posgrad.ufsc.br.

Lucas Kerr Oliveira é Doutor em Ciência Política pela Universidade Federal do Rio Grande do Sul (UFRGS). Professor do Curso de Relações Internacionais e Integração (RII) e do Programa de Pós-graduação em Integração Contemporânea da América Latina (PPG-ICAL), da Universidade Federal da Integração LatinoAmericana (UNILA). Coordenador do Núcleo de Estudos 


\section{Estratégicos, Geopolítica e Integração Regional (NEEGI). E-mail: lucas.oliveira@unila.edu.br.}

\section{Referências}

AGUIAR, Pedro. Agências de notícias, Estado e desenvolvimento: modelos adotados nos países BRICS. Brazilian Journalism Research, v. 12, n. 1, p. 34-59, 2016.

AGUIAR, Pedro. Sistemas Internacionais de Informação Sul-Sul: do pool não-alinhado à comunicação em redes. 2010. 136 f. Dissertação (Mestrado em Comunicação) - Escola de Comunicação da Universidade Federal do Rio de Janeiro, Rio de Janeiro, 2010.

BARDIN, Laurence. Análise de conteúdo. Tradução de Luis Antero Reto e Augusto Pinheiro. Portugal: Edições 70 Ltda, 1977.

BERRINGER, Tatiana. A crise da Unasul e o retorno ao passado. Carta Capital, 17 ago. 2018. Disponível em: <https://www.cartacapital.com.br/blogs/gr-ri/a-crise-da-unasul-e-o-retorno-aopassado/>. Acesso em: 24 set. 2019.

BOCANEGRA, Nelson. Colômbia anuncia que deixará a Unasul em 6 meses. Reuters, 28 ago. 2018. Disponível em: <https://br.reuters.com/article/worldNews/idBRKCN1LD19F-OBRWD>. Acesso em: 17 out. 2018.

BOLIVIA desconoce si hay intenciones de algunos países de dejar la Unasur y prevé una reunión en mayo. EFE, 20 abr. 2018a. Disponível em: <https://www.efe.com/efe/america/politica/boliviadesconoce-si-hay-intenciones-de-algunos-paises-dejar-la-unasur-y-preve-una-reunion-enmayo/20000035-3591359>. Acesso em: 17 out. 2018.

BOLIVIA pide a Colombia "reflexionar" su decisión de retiro de la Unasur. EFE, 12 ago. 2018 b. Disponível em: <https:/www.efe.com/efe/cono-sur/politica/bolivia-pide-a-colombia-reflexionar-sudecision-de-retiro-la-unasur/50000818-3718226>. Acesso em: 17 out. 2018.

BRASIL. Ministério das Relaçóes Exteriores. PROSUL. [Portal do Ministério das Relaçóes Exteriores], 25 set. 2019. Disponível em: <http://www.itamaraty.gov.br/pt-BR/politica-externa/integracaoregional/688-prosul>. Acesso em: 24 set. 2019.

BRASIL anuncia su salida de Unasur tras recibir la presidencia del organismo. EFE, 16 abr. 2019. Disponível em: <https://www.efe.com/efe/america/politica/brasil-anuncia-su-salida-de-unasur-trasrecibir-la-presidencia-del-organismo/20000035-3953734>. Acesso em: 24 set. 2019.

BRASIL aboga en Bolivia por el diálogo para superar los "impases" en la Unasur. EFE, 20 ago. 2018 a. Disponível em: <https:/www.efe.com/efe/america/politica/brasil-aboga-en-bolivia-por-el-dialogopara-superar-los-impases-la-unasur/20000035-3724996>. Acesso em: 17 out. 2018.

BRASIL e outros 5 países suspendem atividades na Unasul. EFE, 21 abr. 2018b. Disponível em: $<$ https://www.efe.com/efe/brasil/brasil/brasil-e-outros-5-paises-suspendem-atividades-naunasul/50000239-3591743>. Acesso em: 17 out. 2018. 
CANAVILHAS, João. Webjornalismo: da pirâmide invertida à pirâmide deitada. Covilhão, Portugal: Universidade Beira do Interior, 2006. Disponível em: <http://www.bocc.ubi.pt/pag/canavilhas-joao-webjornalismo-piramide-invertida.pdf>. Acesso em: 15 jan. 2019.

CANCILLER chileno: Unasur no logró sus fines y está en un "deplorable estado". EFE, 27 abr. 2018. Disponível em: <https://www.efe.com/efe/cono-sur/cronicas/canciller-chileno-unasur-no-logro-susfines-y-esta-en-un-deplorable-estado/50000803-3599365>. Acesso em: 17 out. 2018.

CHANCELER do Equador advoga pela Unasul em visita ao Brasil. EFE, 17 ago. 2018. Disponível em $<$ https:/www.efe.com/efe/brasil/brasil/chanceler-do-equador-advoga-pela-unasul-em-visita-aobrasil/50000239-3722848>. Acesso em: 17 out. 2018.

CHILE formaliza su salida de la Unasur. EFE, 19 jun. 2019. Disponível em: $<$ https://www.efe.com/efe/america/politica/chile-formaliza-su-salida-de-la-unasur/200000354001185>. Acesso em: 24 set. 2019.

CHILE dice que en el escenario regional actual la Unasur "no conduce a nada". EFE, 23 abr. 2018. Disponível em: <https://www.efe.com/efe/america/politica/chile-dice-que-en-el-escenario-regionalactual-la-unasur-no-conduce-a-nada/20000035-3593659>. Acesso em: 17 out. 2018.

COLLING, Leandro. Agenda-setting e Framing: reafirmando os efeitos limitados. Revista Famecos, v. 9, n. 14, p. 88-101, 2002.

COLÔMBIA anuncia que cumprirá promessa de Duque de se retirar da Unasul. EFE, 10 ago. 2018. Disponível em: <https://www.efe.com/efe/brasil/mundo/colombia-anuncia-que-cumprira-promessade-duque-se-retirar-da-unasul/50000243-3717034>. Acesso em: 17 out. 2018.

COLOMBIA da un giro a su política exterior y se retira de la Unasur. EFE, 10 ago. 2018a. Disponível em: <https://www.efe.com/efe/america/politica/colombia-da-un-giro-a-su-politica-exterior-y-seretira-de-la-unasur/20000035-3717008>. Acesso em: 17 out. 2018.

COLOMBIA notifica a la Unasur que deja el bloque por no denunciar la crisis venezolana. EFE, 28 ago. 2018b. Disponível em: <https:/www.efe.com/efe/america/portada/colombia-notifica-a-launasur-que-deja-el-bloque-por-no-denunciar-crisis-venezolana/20000064-3731560>. Acesso em: 17 out. 2018.

COPPPAL cree que el retiro de los países de la Unasur responde a la "estrategia" de EE.UU. EFE, 24 abr. 2018. Disponível em: <https://www.efe.com/efe/america/politica/copppal-cree-que-el-retiro-delos-paises-la-unasur-responde-a-estrategia-ee-uu/20000035-3594108>. Acesso em: 17 out. 2018.

COSTA, Darc A. L. (Org.). América do Sul: integração e infraestrutura. Rio de Janeiro: CapaxDei, 2011.

COSTA, Wanderley Messias da. O Brasil e a América do Sul: cenários geopolíticos e os desafios da integração. Confins, n. 7, out. 2009. Disponível em: <https://journals.openedition.org/confins/6107>. Acesso em: 24 set. 2019.

CRISE na Venezuela leva Colômbia a sair da Unasul. Agência Brasil, 28 ago. 2018. Disponível em: $<$ http://agenciabrasil.ebc.com.br/internacional/noticia/2018-08/crise-na-venezuela-leva-colombiasair-da-unasul>. Acesso em: 26 fev. 2019.

ECUADOR apela al diálogo y la unidad para resolver la crisis en Unasur. EFE, 22 abr. 2018. Disponível em: <https://www.efe.com/efe/cono-sur/portada-cono-sur/ecuador-apela-al-dialogo-y-launidad-para-resolver-crisis-en-unasur/50000831-3592251>. Acesso em: 17 out. 2018. 
EFE. Historia de la agencia EFE. 2020. Disponível em: <https://www.agenciaefe.es/historia-de-efe/>. Acesso em: 14 jun. 2020.

EL CANCILLER de Bolivia confirma la recepción de carta y apela al diálogo en Unasur. EFE, 20 abr. 2018a. Disponível em: <https://www.efe.com/efe/america/politica/el-canciller-de-bolivia-confirmala-recepcion-carta-y-apela-al-dialogo-en-unasur/20000035-3591372>. Acesso em: 17 out. 2018.

EL CANCILLER paraguayo seńala la "crisis" en la Unasur por su viraje ideológico. EFE, 17 ago. 2018b. Disponível em: <https://www.efe.com/efe/america/politica/el-canciller-paraguayo-senala-lacrisis-en-unasur-por-su-viraje-ideologico/20000035-3722938>. Acesso em: 17 out. 2018.

EL KIRCHNERISMO cuestiona que Argentina suspenda su participación en la Unasur. EFE, 21 abr. 2018. Disponível em: <https://www.efe.com/efe/america/politica/el-kirchnerismo-cuestiona-queargentina-suspenda-su-participacion-en-la-unasur/20000035-3592042>. Acesso em: 17 out. 2018.

EL PRESIDENTE de Ecuador convertirá la sede de la Unasur en Quito en una universidad indígena. EFE, 6 jul. 2018a. Disponível em: <https://www.efe.com/efe/america/portada/el-presidente-deecuador-convertira-la-sede-unasur-en-quito-una-universidad-indigena/20000064-3675570>. Acesso em: 17 out. 2018.

EL PRESIDENTE de Ecuador cree que la sede de UNASUR es "un nuevo elefante blanco". EFE, 6 jul. 2018b. Disponível em: <https://www.efe.com/efe/america/portada/el-presidente-de-ecuadorcree-que-la-sede-unasur-es-un-nuevo-elefante-blanco/20000064-3674473>. Acesso em: 17 out. 2018.

EL RETIRO de Colombia de la Unasur refleja el mal momento en la integración, dice Uruguay. EFE, 30 ago. 2018. Disponível em: <https:/www.efe.com/efe/america/politica/el-retiro-de-colombia-launasur-refleja-mal-momento-en-integracion-dice-uruguay/20000035-3733721 >. Acesso em: 17 out. 2018.

ENTMANN, Robert. Framing: toward clarification of a fractured paradigm. Journal of Communication, v. 43, n. 4, p. 51-58, 1993.

EQUADOR se retira da Unasul e afirma que buscará novos marcos de integração. EFE, 14 mar. 2019.

Disponível em: <https://www.efe.com/efe/brasil/portada/equador-se-retira-da-unasul-e-afirma-quebuscara-novos-marcos-de-integra-o/50000237-3924272>. Acesso em: 24 set. 2019.

EXCANCILLER de Bolivia dice que Unasur y Alba tienen que "seguir caminando". EFE, 28 ago. 2018. Disponível em: <https:/www.efe.com/efe/america/politica/excanciller-de-bolivia-dice-queunasur-y-alba-tienen-seguir-caminando/20000035-3732296>. Acesso em: 17 out. 2018.

GOFFMAN, Erving. Frame Analysis. An essay on the organization of experience. Boston: Northeastern University Press, 1986.

GONÇALVES, Hebe M. A Notícia exclusiva na lógica de distribuição em conglomerados da mídia Brasileira: estudo das rotinas nas Agências Estado, Folhapress e o Globo. 2010. 678 f. Tese (Doutorado em Ciências da Comunicação) - Programa de Pós-Graduação em Ciências da Comunicação, Universidade do Vale do Rio dos Sinos, São Leopoldo, 2010.

GRANATO, Leonardo. Brasil, Argentina e os rumos da integração: o Mercosul e a Unasul. Curitiba: Appris, 2015.

GUIMARÃES, Samuel. O mundo Multipolar e a Integração Sul-Americana. Revista Comunicação \& Política, v. 25, n. 3, p. 169-189, 2007. 
HONÓRIO, Karen S. O significado da iniciativa para a integração da infraestrutura regional sulamericana (IIRSA) no regionalismo sul-americano (2000-2012): um estudo sobre a iniciativa e a participação do Brasil. 2013. 133 f. Dissertação (Mestrado em Relaçôes Internacionais) - Programa de Pós-Graduação em Relaçóes Internacionais, Pontifícia Universidade Católica de São Paulo (PUCSP), São Paulo, 2013.

JAEGER, Bruna Coelho. A integração infraestrutural sul-americana: impactos sobre a estratégia e a geopolítica regional. 2014. 97 f. Monografia (Graduação em Relaçôes Internacionais) - Faculdade de Ciências Econômicas, Universidade Federal do Rio Grande do Sul (UFRGS), Porto Alegre, 2014. MADURO pide "consciencia suramericana" a los países que abandonan Unasur. EFE, 21 abr. 2018. Disponível em: <https:/www.efe.com/efe/america/politica/maduro-pide-consciencia-suramericanaa-los-paises-que-abandonan-unasur/20000035-3591456>. Acesso em: 17 out. 2018.

MCCOMBS, Maxuell. A Teoria da Agenda: a mídia e a opinião. Rio de Janeiro: Vozes, 2009.

MENA, Francisco C. Unasur: ¿simple retórica o regionalismo efectivo? Fortalezas y debilidades. Berlin: Friedrich Ebert Stiftung, out., 2013. Disponível em: <http://library.fes.de/pdffiles/bueros/quito/10286.pdfs. Acesso em: 09 dez. 2018.

MORALES dice que se harán todos los esfuerzos para resolver la crisis en Unasur. EFE, 24 abr. 2018 a. Disponível em: <https:/www.efe.com/efe/cono-sur/politica/morales-dice-que-se-haran-todos-losesfuerzos-para-resolver-la-crisis-en-unasur/50000818-3594050>. Acesso em: 17 out. 2018.

MORALES lanza un llamado a la integración para superar crisis en Suramérica. EFE, 5 set. 2018 b. Disponível em: <https:/www.efe.com/efe/america/politica/morales-lanza-un-llamado-a-laintegracion-para-superar-crisis-en-suramerica/20000035-3740431 >. Acesso em: 17 out. 2018.

MORALES plantea el relanzamiento de la Unasur bajo el modelo de la Unión Europea. EFE, 18 abr. 2018c. Disponível em: <https://www.efe.com/efe/america/politica/morales-plantea-elrelanzamiento-de-la-unasur-bajo-modelo-union-europea/20000035-3588406>. Acesso em: 17 out. 2018.

MURFHY, Helen. Colombia's President Duque says will whitdraw from Unasur bloc. Reuters, 27 ago. 2018. Disponível em: <https://www.reuters.com/article/us-colombia-unasur/colombiaspresident-duque-says-will-withdraw-from-unasur-bloc-idUSKCN1LD011>. Acesso em: 17 out. 2018.

PADULA, Raphael. Integração regional de infraestrutura e comércio na América do Sul nos anos 2000: uma análise político-estratégica. 2010. 311 f. Tese (Doutorado em Engenharia de Produção) Programa de Pós-Graduação em Engenharia de Produção, Universidade Federal do Rio de Janeiro (UFRJ), Rio de Janeiro, 2010.

PAGLIARI, Graciela de Conti. Segurança regional e política externa brasileira: as relações entre Brasil e América do Sul, 1990-2006. 2009. 281 f. Tese (Doutorado em Relações Internacionais) Universidade de Brasília (UnB), Brasília, 2009.

PARAGUAI vê como necessário "redirecionar" objetivos da Unasul em crise. EFE, 23 abr. 2018. Disponível em: <https://www.efe.com/efe/brasil/mundo/paraguai-ve-como-necessario-redirecionarobjetivos-da-unasul-em-crise/50000243-3593903>. Acesso em: 17 out. 2018.

PARAGUASSU, Lisandra. Brasil e outros 5 países suspendem participação na Unasul. Reuters, 20 abr. 2018. Disponível em: <https://br.reuters.com/article/topNews/idBRKBN1HR2MH-OBRTP>. Acesso em: 17 out. 2018. 
PARAGUASSU, Lisandra; DESANTIS, Daniela. Argentina, Brasil, Chile, Colombia, Paraguay y Perú suspenden participación en bloque Unasur. Reuters, 20 abr. 2018. Disponível em: <https://la.reuters.com/article/domesticNews/idLTAKBN1HR2J3-OUSLD>. Acesso em: 17 out. 2018.

PARLAMENTO da Unasul na Bolívia recebe críticas por alto custo e inutilidade. EFE, 13 set. 2018. Disponível em: <https:/www.efe.com/efe/brasil/mundo/parlamento-da-unasul-na-bolivia-recebecriticas-por-alto-custo-e-inutilidade/50000243-3748949>. Acesso em: 17 out. 2018.

PREOCUPA a Parlasur decisión de 6 países de suspender participación en Unasur. EFE, 28 abr. 2018. Disponível em: <https://www.efe.com/efe/cono-sur/politica/preocupa-a-parlasur-decision-de6-paises-suspender-participacion-en-unasur/50000818-3599454>. Acesso em: 17 out. 2018.

RAPOPORT, Mario; MADRID, Eduardo. Argentina-Brasil: de rivales a aliados. Buenos Aires: Capital Intelectual, 2011.

REUTERS. Sobre. Reuters, 2020. Disponível em: <https://www.reutersagency.com/pt-br/about/>. Acesso em: 14 jun. 2020.

SANAHUJA, José Antonio; COMINI, Nicolás. Los gobiernos de la nueva derecha y la estrategia de la silla vacía en UNASUR. Open Democracy, 07 maio 2018. Disponível em: $<$ https://www.opendemocracy.net/democraciaabierta/jos-antonio-sanahuja-nicol-s-comini/losgobiernos-de-la-nueva-derecha-y-la-estrate>. Acesso em: 27 nov. 2018.

SCHMITZ, Aldo Antonio. Fontes de notícias: ações e estratégias das fontes empresariais nas relaçóes com jornalistas de economia e negócios. 2010. 152 f. Dissertação (Mestrado em Jornalismo) Programa de Pós-Graduação em Jornalismo, Universidade Federal de Santa Catarina, Florianópolis, 2010.

SEIS países de la Unasur anuncian que dejarán de participar en ese bloque. EFE, 20 abr. 2018. Disponível em: <https://www.efe.com/efe/cono-sur/politica/seis-paises-de-la-unasur-anuncian-quedejaran-participar-en-ese-bloque/50000818-3591395>. Acesso em: 17 out. 2018.

SPEKTOR, Matias. Unasul precisa ser chacoalhada, não fechada. Folha de S. Paulo, 26 abr. 2018. Disponível em: <https://www1.folha.uol.com.br/colunas/matiasspektor/2018/04/unasul-precisa-serchacoalhada-nao-fechada.shtml>. Acesso em: 26 fev. 2019.

TUCHMAN, Gaye. Making News: a study in the construction of reality. New York: The Free Press, 1978.

UNIÃO DE NAÇÓES SUL-AMERICANAS (UNASUL). Decisão No 001/2016. Caracas, 25 ago. 2016. Disponível em: <http://www.itamaraty.gov.br/images/ed_integracao/docs_UNASUL/DEC001.2016POR.pdf>. Acesso em: 26 nov. 2018.

URUGUAY se mantiene en la Unasur pese a que sus vecinos le dan la espalda. EFE, 24 abr. 2018a. Disponível em: <https://www.efe.com/efe/cono-sur/portada-cono-sur/uruguay-se-mantiene-en-launasur-pese-a-que-sus-vecinos-le-dan-espalda/50000831-3594034>. Acesso em: 17 out. 2018.

"URUGUAY no piensa salirse de la Unasur", asegura el canciller. EFE, 21 abr. 2018b. Disponível em: <https://www.efe.com/efe/america/politica/uruguay-no-piensa-salirse-de-la-unasur-asegura-elcanciller/20000035-3592066>. Acesso em: 17 out. 2018. 
238 | Beatriz Soares Bidarra, Jéssica Maria Grassi e Lucas Kerr Oliveira

VALENCIA, Alexandre; LLANGARÍ, José. Ecuador anuncia su retiro de Unasur, pide revertir el edificio de la sede. Reuters, 13 mar. 2019. Disponível em: <https://ta.reuters.com/articulo/politicaecuador-unasur-idLTAKCN1QV01Y>. Acesso em: 24 set. 2019.

VIZENTINI, Paulo G. F. América do Sul: espaço geopolítico prioritário do projeto nacional brasileiro. In: REBELO, Aldo; FERNANDES, Luis; CARDIM, Carlos. (Orgs.). Política externa do Brasil para o século XXI. Brasília: Câmara dos Deputados, 2003. p. 183-211.

Texto recebido em 15 de dezembro de 2019. Aprovado em 19 de junho de 2020. 